\title{
A educação básica pública tem solução? de Herman J.C. Voorwald
}

São Paulo: Unesp, 2017. 117 p.

\section{Carlos Lima Dantas}

Mestrando do Programa de Mestrado em Gestão e Práticas Educacionais da Universidade Nove de Julho. São Paulo - SP - Brasil carloslimadantas@hotmail.com

presente obra destaca-se dentre os aspectos editoriais, pela autoria e re-
tórica relacionada a atuação e formação acadêmica do autor, indo ao encontro das ciências da natureza, gerencialista, lógica e exata.

Para isso, destacadamente relembro que Herman J.C. Voorwald é engenheiro mecânico, mestre e doutor em Engenharia Mecânica. Logo, sem muitas dificuldades, facilmente seria possível afirmar que pouco ou quase nada teríamos a saber daquilo que defronte da sua avaliação sobre a educação e os seus mecanismos pedagógicos que por ora, aprofundaria tal análise sobre esta natureza humana e dialética. A linha de pensamento, naturalmente estaria correta, se não levássemos em consideração um dos cargos mais significativos exercido em sua trajetória profissional: Secretário de Educação do Estado de São Paulo, entre o período sabático da reorganização das escolas, onde na oportunidade, ocorreram as ocupações dos estudantes nas instituições. Diante desta lembrança, a leitura do livro tornou-se cômoda e, principalmente fundamental no propósito de descoberta das motivações e razões que teriam levado o Secretário de Educação - cargo político - dissertar sobre o assunto: educação básica.

Cadernos de Pós-graduação, São Paulo, v. 17, n. 2, p. 263-267, jul./dez. 2018. 
Sem muitos imbróglios, exercido naturalmente pela "mecânica" do autor, o livro divide-se em 5 capítulos, sucintos, apontando as definições históricas e administrativas no papel do estado à frente dos problemas encontrados na educação, desde o permeio das políticas públicas àquilo que contribui de maneira positiva e também negativa aos índices de avaliação deste sistema. Vamos imergir nestes capítulos:

No primeiro denominado Algumas palavras sobre o contexto histórico, o autor traça um panorama histórico, daquilo que foi inerente à concepção da educação, datados pela constituição de 1824, nela situada como elemento aos direitos civis e políticos. Naturalmente neste discorrer, dados, números e estratégias são citados, de modo a fundamentar e aprofundar a análise no contexto científico e qualitativo destes recursos adotados. Os desafios e os índices qualitativos do Sistema de Avaliação de Rendimento Escolar do Estado de São Paulo (Saresp) são notoriamente destacados, tal como a gestão de carreira do profissional de educação.

O segundo capítulo, Politicas públicas e educação - diálogo e compromisso, encaminhase para uma espécie de diário profissional, onde o autor, por vezes, cita sua experiência à frente da Secretaria da Educação. Curiosamente, destaca-se o diálogo daquela oportunidade com os supervisores, diretores, professores, coordenadores de oficinais pedagógicas, professores coordenadores e membros dos quadros de apoio escolar da Secretaria da Educação, mostrando-se presente os anseios e, principalmente as referências deste grupo às pautas relacionadas aos recursos humanos, totalizando $61,8 \%$ das manifestações, sistematizadas pelos 5.389 servidores.

No terceiro capitulo: Reestruturação da Secretaria da Educação do Estado e o Programa Educação: compromisso de São Paulo, a abordagem está voltada na restruturação que ocorreu no sistema educacional no ano de 2012, de modo ambicioso, concebido para delinear de maneira clara os encargos administrativos e para realizar um resgate histórico, traçando um paralelo entre as mudanças socioeconômicas e a política de educação. 
Num sobrevoo pelas políticas educacionais, o autor traz à tona, neste capitulo, as ações governamentais que apontaram para as diretrizes e valores relativos aos processos de formação no âmbito escolar. Neste passeio histórico, destaca-se a ótica observacional da década de 1970 e o surgimento das palavras "eficiência", "controle”, "planejamento" e "avaliação" como definição de metas e mediação de resultados.

Nessa sessão o livro, destaca-se pela extensão de dados e informações administrativas sobre as estratégias e planos traçados pelo Estado para conter a abrasividade na educação e manter de maneira satisfatória, os resultados apontados nos índices e avaliações. Para isso, nota-se a abordagem prescritiva em três níveis lógicos: Controle-padronização, centralização e estruturação, detalhadamente expostos, neste primeiro nível por cincos pilares: 1- Valorizar e investir no desenvolvimento do capital humano da secretaria; 2- Aprimorar as ações e a gestão pedagógica da rede com foco no resultado dos alunos; 3- Expandir e aperfeiçoar a política de educação integral; 4- Viabilizar mecanismos organizacionais e financeiros para operacionalizar o programa; 5- Mobilizar, engajar e responsabilizar a rede, os alunos e a sociedade em torno do processo de viabilização da aprendizagem; devidamente contemplados nestes pilares as nove áreas nas quais foram agrupadas as manifestações dos profissionais da educação discutidas no segundo capítulo, sendo elas: comunicação, formação continuada, gestão de infraestrutura, gestão de recursos humanos, gestão institucional, programas e projetos, gestão de ensino, informação, monitoramento e avaliação, orçamento e finanças.

Quarto capítulo, oportuno, indo ao propósito de identificar os desafios deste sistema, nomeia-se como $O$ desafio da melhoria da qualidade, como não poderia ser diferente de seu título, o autor aprofunda-se na problematização e nos aguilhões expostos do capítulo anterior, onde os dados suspostamente apontam a melhora, segundo a ótica do autor, naquilo que foi traçado como objetivo pelo Estado, dentre os vários aspectos destacados neste fragmento do livro, estão, o ensino integrado, a flexibilização da grade 
e o aumento da carga horária, tal como a concentração das demandas levantadas pelos profissionais da educação pública paulista.

No último capítulo denominado Propostas - apresenta-se como uma espécie de filé do cardápio, prato principal, o caviar do livro. O autor faz um paralelo aos fatores históricos, sobretudo na discrepância social que nos trouxe até a situação existente, usada como escudo por governantes para a implementação de novas, diferentes e ousadas políticas públicas, como mecanismo de transformação. Descreve de maneira dominante, como as universidades públicas paulistas tornaram-se referência nacional e internacional, agindo de maneira independente às ações administrativas por meio do Plano de Desenvolvimento Institucional (PDI). Neste momento do livro, o autor comunica-se de maneira célebre aos pilares discutidos no terceiro capítulo, propondo de maneira pontual as Propostas, tal como o nome do capítulo, aquilo que tivera sido identificado pelo Estado durante sua tratativa de governo, discorrendo numericamente por cada um deles.

A divisão do livro, destaca-se pela a abordagem da reorganização da rede pública estadual, enfatizando as questões: estrutura física, logística e humana (pessoas), no que diz respeito a tal reorganização, o tamanho da escola torna-se o objeto analítico no contexto do autor, principalmente quando tal espaço, mostra-se amplo no sentido espacial, tendo seu uso destinado ao programa de ensino integral.

Entre as Propostas e reflexões do autor a respeito dos pilares e das estratégias expostas ao longo dos capítulos, a última parte do exemplar do material impresso, notadamente reforça a relevância da leitura quanto ao tema, sobretudo do conteúdo do livro e da abordagem cotidiana e trivial no exercício do cargo de secretário ocupado pelo autor durante o processo de coleta e laboratório do tema discutido nas páginas do livro, para isso a imersão nos capítulos remete de maneira clara o cenário atual das 
políticas, e principalmente das práticas educacionais presentes no ambiente escolar, exercido rotineiramente pelos profissionais de educação.

Diante do exposto a leitura da obra, torna-se relevante e principalmente indicada, uma vez que as informações presentes vão ao encontro da complexidade do ambiente administrativo, político e sobretudo participativo da rede, refletindo de maneira natural ao entendimento e aplicabilidade dos recursos financeiros, humanos, institucionais e infraestrutural, vigentes na gestão escolar deste a sua concepção neste modelo gerencialista.

A leitura provoca de maneira natural a questão: seria utópico pensarmos em um sistema de educação pública brasileiro entre os 25 melhores do mundo?

O livro fornecerá as instâncias necessárias para a resposta, reflexão e compreendimento deste horizonte, sob a ótica do autor e Secretário de Educação do Estado de São Paulo. 